\title{
OUTSIDE THE SECOND SEX: BEAUVOIR'S "PENSÉE DU DEHORS"1
}

As desire, consciousness is outside itself; and as outside itself, consciousness is self-consciousness. Clearly, the meaning of this 'outside' is yet to be clarified. (Butler 1987, 7)

\section{"Le dehors": The Outside}

We new postructuralists, awaiting the turn of the millennium, are by now abundantly familiar with the old "Il n'y a pas de hors texte"; or, as its inversion suggests: le dehors c'est le texte. But having read Beauvoir, we know this outside as a text in its own right: a text that breathes, that feels, resists, cries, laughs, bleeds... a text that "becomes"...that becomes "(a) woman." "Je ne suis pas d'abord chose," she writes in Pyrrhus et Cinéas, "mais spontanéité qui désir, qui aime, qui veut, qui agit" $(1947,245)$.

Thus one might notice that "On ne naît pas femme: on le devient," rendered into English by H. M. Parshley as "one is not born, but rather, becomes, a woman" $(1989,267)$, features a peculiarity that is lost. The French possibility of a masculine article -- "le" -- in this context sounds the difference between woman as a project and a fate. How different would it have sounded to us had she written: "on $l a$ devient"! And yet this is an ingenious difference lost in a différance of

\footnotetext{
${ }^{1}$ Versions of this paper were given at the "Cinquantenaire du Deuxième Sexe" Conference in Paris, January 17-21, 1999, and at the "Legacies of Simone de Beauvoir" Conference at Penn State University, November 19-21, 1999. I wish to thank my students at the Simone de Beauvoir Institute for the opportunity to develop these ideas in my teaching as well as in the Research Associates Seminars where I could play them off my colleagues. Special thanks to Barbara Cadorette for her gift of the "other" Second Sex. Some of the ideas in this piece are also developed in my guest edited "Heritage In-Situ" issue of the Simone de Beauvoir Institute Review 18/19 (2000a) celebrating Beauvoir's 50-year legacy of feminist thought. These ideas were also developed and presented in French version in a paper entitled "Simone de Beauvoir: Un Héritage du Dehors" at the "Le deuxième sexe: Une relecture en trois temps, 1949-1971-1999" Conference at the University of Ottawa, Colloque annuel de la Faculté des sciences sociales, 14 - 15 october, 1999 (see Alexander 2000b).
} 
translation $^{2}$ that shies from the preposterous: "one becomes it." The single most important insight of her thought -- that "one" may indeed not become "it" at all -- eludes us as she slips into a rift, dispersing into the naked space of the outside. Half a century later we are left to ponder the enigmatic succor of Beauvoir's failing in our language as, the worlds over, others ponder it in theirs.

Through structures of language, through structures of feeling...through the "imaginary domain," Beauvoir's body of work shows us the hidden face of the "outside" by analysis as much as by example: for those of us who have followed its turns, this is a twisting, Moebian "outside," already inside; the instance and the principle.

The following links the origins and the timeliness of this master opus through the concept of the "outside" (Deleuze 1986; Foucault 1987; Levinas 1994; Sartre 1992; inter alia), a concept which, I argue, also forms an integral part of the text itself, its structure and its meaning. I wish to present 'the outside' as the site of passage of a work that has so spectacularly affected the history of women, the history of women's studies, of feminism, and of philosophy, a text that has so deeply been absorbed into the manifestations of our time, that it has virtually disappeared.

Elsewhere I have argued that Simone de Beauvoir has been so deeply buried in the fabric of our times that we have lost sight of her distinctiveness (Alexander 1997). Following a current move in France and America today (as well as the world over) to examine the deeply buried, hidden, philosophical aspects of our feminist legacy, ${ }^{3} \mathrm{I}$ wish to now engage with the very vital connection between Beauvoir's "thought" and a certain marginal, intellectual counter-cultural tradition in Europe during her time that includes the likes of Nietzsche, Sade, Bataille, Klossowski, Blanchot; a tradition that does not necessarily reflect the more mainstream philosophical models of Sartre and Merleau-Ponty. The essay lingers on the submerged ties between her work and what Foucault, in his wonderful essay on Blanchot and this

\footnotetext{
${ }^{2}$ See my article "The Eclipse of Gender: Simone de Beauvoir and the Différance of Translation" (Alexander 1997) for a fuller discussion of this idea.

${ }^{3}$ See Sylvie Chaperon, "Le deuxième sexe en `héritage,"' Monde Diplomatique, janvier 1999.
} 
renegade culture, calls: "a thought from (the) outside" (une pensée du dehors). ${ }^{4}$

I will explore this Beauvoirian "outside (of) thought" as the altered ground for a postmodern feminist ethic; a future-oriented feminist "thought" of lived experience, situation, embodiment: a fully feminist and unstoppable contemporary thought of/from the outside. I argue that such a "thought" is not only itself outside of the counter-tradition from which Beauvoir herself emerged, it also enables us to take the past along with us and simultaneously move beyond.

The essay argues that her intellectual debt to this "outside (of) thought" -- often reflected in Beauvoir's less known works such as Pyrrhus et Cinéas (1994; 1947), Pour une morale de l'ambiguïté (1947), The Ethics of Ambiguity (1991), Faut-il brûler Sade? (1953), The Marquis de Sade? (1955), "La phénoménologie de la perception de Maurice Merleau-Ponty," in Les Temps Modernes (1945) and L'Amérique au jour le jour (1948), America Day by Day $(1952)^{5}$-- has not only deeply contributed to her philosophical models. It also marks the com/memorable site of a distinctly Beauvoirian turn in the history of our era: the making of modern feminism.

Read together with Tomes I and II of Le deuxième sexe (1949), known to us in English as The Second Sex $(1952 ; 1989)$, Beauvoir's collected opus celebrates the hitherto "unthought" of possibility of feminism as the work of a "heritage in-situ" (Alexander, 2000). Through this latent legacy of exteriority and location that marks the absorption of her work, Beauvoir's work offers feminist discourse an escape, an a-topical place of 'exit,' and a spectacular 'way out' of some of the more paralysing and perplexing dilemmas, paradoxes, and polarizations that have beset Women's Studies, social life, and the modern Academy generally.

\footnotetext{
${ }^{4}$ I have not been able to find an adequate translation for Foucault's term (also taken up by Deleuze "pensée du dehors," also taken up by Deleuze (Deleuze 1986), so I have left it as is. It has been translated by Brian Massumi as "the thought from (the) outside" (Foucault 1966).

${ }^{5}$ I might also include Beauvoir's study of Old Age (1977) and her essay "Pyrrhus et Cinéas" published only in French together with Pour une morale de l'ambiguïté (Paris: Gallimard, 1944; 1947).
} 


\section{The Other Second Sex}

My ruminations, begun several years ago, gain further impetus today as I discover the back jacket of the Four Square British edition (1960) of what is presented as Simone de Beauvoir's The Second Sex, purportedly an English translation of Le deuxième sexe. Citing applause from the respectable British review The Guardian, it reads: "The subject is woman in all her aspects, and out of it Mlle. de Beauvoir has produced a book which may well become a classic of its kind...she believes that women are inferior to men only because they are made so" (my emphasis).

Thus I find that the already fragmentary and watered-down Parshley translation of Beauvoir's Le deuxième sexe that we in America know as the founding tome of modern feminism, The Second Sex has audiences in another, even more remarkable, mutation: comprising only of the second tome of the original, minus any table of contents, index, epigraph, or preface what appears before me today, in a somewhat dilapidated but nevertheless concrete form, is another Second Sex, indeed, another Beauvoir. This is a Beauvoir that believes not that we (women and men) think that women are made inferior, but that they are so. "To be" and "to be made" are manifested completely outside the "to think." Yet wasn't it precisely in the originality of Beauvoir's thought that she showed show us otherwise? Not because there is an absolute truth to "thought," but precisely because there is none?

So what is one to make of such a complete, total, and uncompromised subversion of her text? Its complete submission to what is outside itself? Into the empty chasm that divides essence and existence, the "I am..." and the "I think that I am...," Beauvoir's The Second Sex -- indeed her entire corpus -- escapes (into) its own monumental history. ${ }^{6}$

A distinctly "modern" possibility this disappearance is, according to Foucault, one that emerged along with "the event that gave rise to what we call 'literature'" (Foucault 1987; my emphasis). It is characterized by a "doubling back" that enables the subject to designate itself. Foucault writes: "this self-reference supposedly allows it [the subject that speaks] both to interiorize to the extreme (to state nothing but itself) and to manifest itself in the shimmering sign of its distant existence" (ibid., 12). In this "passage to the 'outside'" that Foucault

\footnotetext{
${ }^{6}$ For a more detailed discussion of this point see Alexander (1997).
} 
describes, the space of language is a space that "simultaneously holds and separates." He writes:

Language escapes the mode of being discourse -- in other words the dynasty of representation -- and literary speech develops from itself, forming a network in which each point is distinct, distant from even its closest neighbours, and has a position in relation to every other point in a space that simultaneously holds and separates them all. (ibid; my emphasis).

It is this "space" that we are interested in here: a space where being and (the being of) language spectacularly mesh and where Beauvoir's The Second Sex finds its heritage and its home.

If the space into which our heroine disappears manifests itself to us as "the void language takes as its space when it articulates itself in the nakedness of 'I speak'" (ibid., 12), Foucault reminds us that this "void" is not an empty space. The "outside in which the speaking subject disappears" (13), is "an absolute opening through which language endlessly spreads forth" in its raw state (ibid., 11) and announces, by virtue of its pure exteriority, the unfolding of the very "being of language" itself (ibid., 13).

This "thought," found in modern literature and philosophy, is, according to Foucault, borne out of an "experience of the outside" (ibid., 17). It moves from the out-of-body ex-static experience of mystical thinking, ${ }^{7}$ through the baring of "desire as the lawless law" in

\footnotetext{
${ }^{7}$ In his article "Maurice Blanchot: The Thought From Outside" (1966), Foucault traces "the fundamental forms and categories of this 'thought from outside"' retracing its path "to find out where it comes to us from and in what direction it is moving" (ibid., 16). Foucault assumes that it was born of the mystical thinking "that has prowled the borders of Christianity," surviving in forms of "negative theology," and moving from the "experience of going 'outside oneself" which is "done ultimately in order to find oneself, to wrap and gather oneself in the dazzling interiority of a thought" (ibid., 16) to an experience that "was afterward to remain not exactly hidden, but because it had not penetrated the thickness of our culture, but afloat, foreign, exterior to our interiority for the entire time the demand was being formulated,
} 
the work of the Marquis de Sade (ibid., 17), up to the second half of the nineteenth century, when "thought [itself], forsaking the wordy interiority of consciousness, becomes a material energy, the suffering of the flesh, the persecution and rending of the subject itself" (ibid., 18). It is "a form of thought whose still vague possibility was sketched by Western culture on its margins. A thought that stands outside subjectivity, setting its limits as though from without, articulating its end, making its dispersion shine forth, taking in only its invincible absence" (ibid., 15). A thought that:

at the same time stands at the threshold of all positivity, not in order to grasp its foundation or justification but in order to regain the space of its unfolding, the void serving as its site, the distance into which it is constituted and into which its immediate certainties slip the moment they are glimpsed -- a thought that, in relation to the exteriority of our philosophical reflection and the positivity of our knowledge, constitutes what in a word we might call 'the thought from the outside' (ibid., 15-16; my emphasis).

For Foucault, Blanchot, Bataille, Klossowski, Artaud, Sade, Nietzsche, Mallarmé all share a discourse of contradiction, limit, rupture, duplicity, and the multiplication of the self, that places them in an "outside" position (ibid. 17-18). To this small illustrious crew we now add another name.

Indeed, let us consider (the matter of) the origin and timeliness of Simone de Beauvoir's The Second Sex as "a subject (matter) of the outside." Said to have launched the modern feminist discourse on gender, Le deuxième sexe, along with its English rendition The Second Sex, is a treatise on woman, and on women, that does not itself need or discursively depend upon "gender." Without recourse to the pre-given and prefigured concept of "gender," Beauvoir's proto-feminist thought is, indeed, outside gender. It resides so fully in the matter of the outside that it expresses the materiality of both language and the social.

most imperiously, to interiorize the world, to erase alienation..." (ibid., 17). 
One has only to think of the remarkable Japanese translation in which "femininity" and "motherhood" are translated interchangeably! ${ }^{8}$ Or of the Swedish translation that evacuates the chapters on the lesbian, the mother, and the prostitute. ${ }^{9}$ Even in its original French version, the text is equally elusive. According to Toril Moi, only the Gallimard Edition "Blanche" is complete. ${ }^{10}$ And again, how "complete," one wonders? One has only to think of all the preceding archived versions in-progress to begin to realize that The Text of this pioneering feminist work may exist nowhere in space; no place we can lay hold of it unambiguously. The singularities make of Beauvoir's work an "experience of the outside" that is both instance and principle of the enormity of her "thought."

In the remainder of this essay, I will explore the space of "the outside," in the Foucauldian sense of a space that simultaneously "holds and separates," as a live "element" of The Second Sex, and will present it as at once: a) a surface, b) a threshold, c) a boundary, and d) an experience of the multiplicity of heterogenous spaces of culture and life. Along the way I will reflect upon modern Beauvoirian feminism as a subject "outside itself," a subject outside the dualities of binary and hierarchical thinking (inner/outer, singular/plural, personal/political, autonomy/dependence, pleasure/pain). In conclusion, I will discuss the value of this exteriority in performing the ethical and political task of feminism at hand.

\section{Outside (of) Philosophy}

"In what extreme delicacy," asks Foucault, "at what slight and singular point, could a language come together in an attempt to

${ }^{8}$ Takako Inoué, "La réception du Deuxième sexe au Japon et ses deux traductions en langue japonaise." Unpublished paper presented at the "Cinquantenaire du Deuxième Sexe" Conference in Paris, 19-22 January, 1999.

${ }^{9}$ Sylvie Camet, "La réception du 'Deuxième Sexe' en Suède," paper presented at the 8th International Simone de Beauvoir Studies Conference, "L'engagement d'une oeuvre et d'une vie/A Life-time of Commitment and Writing," Trent University, Peterborough, Ontario, 26-29 may, 2000.

${ }^{10}$ Toril Moi, "(Mis)Reading The Second Sex: Questions of Equality and Difference Prefaced by Some Reflexions on the General Tendency to Debasement of Beauvoir," Keynote Address, "Legacies of Simone de Beauvoir" Conference, Penn State University November 19-21, 1999. 
recapture itself in the stripped-down form, "I speak"? Unless of course, the void in which the contentless slimness of "I speak" is manifested were an absolute opening through which language endlessly spreads forth..." (Foucault 1987, 11).

Let us suppose that the substance of language is a "substance" with no core: only the surface of an outside; let us take "intertextuality" as the subject's "passage to the outside," and let us consider how a book in two tomes titled Le deuxième sexe filtered through the outer bounds of an outside already inside. We cannot but now recognize "the fullness of the void" (Foucault 1987, 23) in which the contentless slimness of "I am a woman" [or, in a more complex manner "On ne naît pas femme: on le devient"] is manifested when it slips back into the outside.

Let us take this "void" as what Foucault calls "an absolute opening" and see how through this text, in all its différance, its different languages, cultures, its variations and permutations, endlessly spreads forth, while she, the subject -- the "I", the woman, who speaks, Beauvoir -- fragments, disperses, scatters, disappearing in "that naked space." In the "spreading forth of language" Beauvoir's spectacular corpus speaks, "in its raw state, it is an unfolding of pure exteriority" (ibid., 11) and its author -- Beauvoir -- disappears in "the void that language takes as its space" (ibid., 12). This "outside in which the speaking subject disappears" (ibid., 13) is, I contend, the sparkling space in which Beauvoir and her master work take their place.

Thus it is that Simone de Beauvoir describes her incentive to write The Second Sex as follows: "One day I wanted to explain myself to myself...And it struck me with a sort of surprise that the first thing I had to say was`I am woman'"(1989). The result has not only been the founding tome of modern feminism, but a radical break with a philosophical tradition from whose entrails she herself had sprung in a most peculiar way. "These problems that he lives with his brain," she writes about fellow student Merleau-Ponty "I live with my arms and my legs..." (quoted in Simons 1997; Simons 1999b, 205).

Beauvoir is perhaps more than a simple witness to this outside (thought). Like Foucault's Blanchot, Simone de Beauvoir has been so deeply buried in the fabric of our times -- the living tissue of our "women's time" (Kristeva 1981) -- that we have lost sight of her distinctiveness. Just the idea that Beauvoir has been translated into 121 languages and that we have still not fully grasped the import of her 
work, is a measure of the scope and magnitude of that "thought." A "thought" banished or absorbed into the climate and the prejudices of our times, sometimes without so much as a trace (the expurgated Swedish edition apparently appears to be complete, and the Four Square Edition likewise)! So far has she withdrawn into the manifestation of her work, so completely is she, not hidden by her texts, but absent from their existence and absent (like Blanchot) by virtue of the marvellous fact of their existence, that for us she is that outside (thought) itself, what Foucault in his wonderful essay on Blanchot calls: the thought from outside.

But although swallowed into her times (unlike Merleau-Ponty, Sartre and the rest) by a force that we have yet to fully understand, Beauvoir did not herself emerge out of a void. In her resolute rejection of the "naturalist" tendencies to be found in the patriarchal accounts of woman as Other, Simone de Beauvoir relied on her contemporaries: a "literary and cultural avant-garde" of the times (Schrift 1995, 3), a counter-cultural group of intellectuals the likes of Sade, Nietzsche, Bataille, Blanchot, Klossowski, Merleau-Ponty, et al. In breaking and in sharing with a "thought" that broke out during the latter half of 19th century, and in which the subject of language made its brief and distinctive dis/appearance -- like a "wrinkle" in the sand (Foucault 1970, xxiii) -- Simone de Beauvoir's radical philosophy of Woman as the Other, as an "outside" already inside, ${ }^{11}$ gives out to the smooth spaces of feminism. Beauvoir's "pensée du dehors" (Foucault 1987; Deleuze 1986) is a "féminisme engagé," to be made and remade in the eyes, hearts, ears, arms, legs, and feelings of each successive generation, as we make meaning matter. A feminism "without-walls" is a feminism of the outside in which after Man, Woman, too, would disappear, "like a face drawn in sand at the edge of the sea" (Foucault 1970, 387).

\section{Feminism from the Outside}

It was indeed Judy Butler who first raised the question of the 'outside' within feminist discourse, only to leave us hanging: "clearly

${ }^{11}$ Drucilla Cornell points out how Beauvoir's account of woman's definition as "Man's Other" shows how that definition does not properly recognize woman's otherness at all (Cornell 1992, 55). As Butler puts it: "the construction of an "outside" that is nevertheless fully "inside," [is] not a possibility beyond culture, but a concrete cultural possibility that is refused and rediscribed as impossible" (Butler 1990, 77). 
the meaning of this outside is yet to be clarified," she writes in 1987 (Butler 1987, 7). We (in feminism) have since not come much farther.

Although there have been some further feminist reflections on the space of "the outside" (Butler 1993; Grosz 1996; Probyn 1996) in recent years, many have shown a tendency to romanticise it. With the aura of images (the Moebius band) or the power of rhetoric, they chirpily present the outside as a somehow privileged space. Nevertheless its social, political and philosophical meaning still remains, more than a decade since Butler's study of Hegel, obscure. What is the status of this "outside" ? ${ }^{12}$ What is the significance of the fact that difference (anatomical, biological, racial, etc.) is only "given" through its signification, and yet "[it] appears to exceed that signification, to provide the elusive referent in relation to which the variability of signification performs" (ibid., 90)?

These are questions that return, unanswered and unaddressed by contemporary feminist theorizing. The "feminine" as the "constitutive outside" (Butler 1993, 35) of a phallogocentric economy of meaning sits uneasily next to the demand to meet the needs of women whose situation exceeds, is indeed almost outside, the limits of gender: e.g. outside the limits of the representations of their sex. We have only to think of the populations of women that do not classify as women, eg."proper" women: lesbians, bisexuals, prostitutes, postmenopausal, disabled women, inter alia.

If as Butler warns "language [is] also the condition under which materiality may be said to appear" $(1993,31)$, what indeed IS the status of this outside? What of "those 'unlivable' and 'unhabitable' zones of social life which are nevertheless densely populated" (ibid., 3)? What of "a constitutive outside of the subject, an abjected outside"

12 "The materialist picture of evolution as natural selection operating purposelessly, yet efficiently developing life forms through random mutation from a definite beginning-point within a finite theatre of planetary environment needs sone revision" (Robert A. F. Thurman, "What Is Death?" Tricycle: The Buddhist Review, Fall 1997: 27-29.). Given the boundless interconnectedness of living forms, beginninglessness and endlessness, and spread throughout an infinity of space (Thurman, ibid.), it is possible to theorize the "spreading forth of language in its raw state, an unfolding of pure exteriority" (Foucault 1966, 10). 
(ibid.) populated by women? According to Butler, it is this "constitutive force of exclusion, erasure, violent foreclosure, abjection" (ibid., 3) that accounts for how the bodies of women "fail to materialize [and] provide the necessary 'outside,' if not the necessary support, for the bodies which, in materializing the norm, qualify as bodies that matter" (ibid., 16). The place of women as subjects of the outside materializes painfully before us. Consider for example, Virginia Woolf's eloquent eulogy to woman's exteriority in Three Guineas: "As a woman I have no country. As a woman I want no country. As a woman my country is the whole world" (Woolf 1977). Of course, that exteriority has been experienced as the mark of an interiority or domesticity that has been the dual site of woman's oppression and her liberation. Unlike the abstract space of philosophical interiority that marks the history of Western thought, with its inside-outside division, domesticity is a space and a place that has always held an ambiguous meaning for women. ${ }^{13}$

We are now in a position to see that the "place" of women as others, as "outsiders," across the globe and amongst all cultures, offers up a structural conundrum that Beauvoir broke through. Properly understood, Beauvoir's view from outside (her existential philosophy of the Other) is a powerful operational "lever" (Le Doeuff 1989) for treating (analyzing, diagnosing) women in all their "wild singularity" (a Deleuzian phrase) as well as in changing political and historical, cultural contexts. To follow Beauvoir into the "post" -- into the "outside" and beyond -- is to give over to the new anti-naturalist tendencies today, ones which are nevertheless complicit with a bodily and fully situated and material social existence: with prosthetic bodies and mutant selves, with the abject and the derelict, the outsiders that we see on the streets, in the alleys, in coffee-shops, or "bawdy houses"; on the big and little screens; or those outsiders, everyday home bodies tucked away in some domestic nightmare or even conversely magic dream.

In this respect if Beauvoir is outside philosophy, it is that she is also a philosopher of the "outside," of the "being" of language and desire. Her powerful phenomenological philosophy of existence lends

${ }^{13}$ For a discussion of this meaning see my essay "The Double Meaning of Estia: Gender, Spirituality, and Signification in Greek Antiquity" Women and Language 16, 1 (Fall 1993): 1-6. See also my unpublished dissertation "The Space That Claws and Knaws: Topoi of a Critical Discourse on 'Home,"' Concordia University, Montrèal, 1992. 
itself to a new interiority (an inside already outside): one carved out of an endless possibility of surface effects, inscriptions, marks, "scars, disfigurements, discolorations, damages, losses, as well as what pleases" (Rich 1986, 215) -- effects that make each one of its subjects an almost un-replicable configuration of terms, experiences, fluxes, intensities, flows. It is the nature of precisely this effect -- an effect of the subject's immersion in language and meaning -- that "horrified" the Cartesian philosophers of the interior from whose "tradition" she, and others like Blanchot, emerge; it is also the nature of the particular "gift" that feminism enjoys: not emanating from any "lack," nor of women as "lack", but from the richness of the "void" that grounds -- in a "space that simultaneously holds and separates" (Foucault 1987, 12) -- the sailing forth, the upsurge, indeed the "imperative" (Lingis 1998) of our outside and material existence as touched and vulnerable, feeling human beings.

\section{Beauvoir's "Pensée du dehors"}

"The whole of feminine history has been man made," writes Beauvoir in The Second Sex (Beauvoir 1989, 128) selling millions of copies of a book that survived in the immediate negation of what it says. The idea that women are not 'naturally' destined, indeed naturally "made," for marriage and motherhood was, and continues to be, a view that provokes a "widespread hostility" (Kruks 1989, 59). If woman's condition has been, as she argued, humanly created, it cannot be explained as a 'biological destiny.' As Sonia Kruks points out: "we must look rather to human relations as an explanation' (ibid., 59). This means: it is to the outside we must look.

However, this "outside" is not the outside as an inner confirmation, "a kind of central, unshakable certitude" (Foucault 1987, 21-2); but as a movement "toward an outward bound where it [thought] must continually contest itself" (ibid., 22). For, as Foucault explains in his dazzling essay on Blanchot that belongs to Simone de Beauvoir: "When language arrives at its own edge, what it finds is not a positivity that contradicts it, but the void that will efface it. Into the void it must go, consenting to come undone in the rumbling, in the immediate negation of what it says, in a silence that is not the intimacy of a secret but a pure outside where words endlessly unravel" (ibid., 32). In the words of Blanchot himself, this outside is "less than the abyss of the void; [than it is] the fullness of the void, something one cannot silence, occupying all of space, the uninterrupted, the incessant, a tremor and 
already a murmur, not a murmur but speech, and not just any speech, distinct speech, precise speech, within my reach" (Foucault 1988, 23). ${ }^{14}$

My argument here is that, consenting to come undone in the manifold versions of The Second Sex and contesting itself further in the immediate negation of itself, Beauvoir's philosophy of the outside is made to come within the "reach" of each of us. This reach can bring us, at long last, "beyond" the notorious "Second Wave" of feninism -- for, as we painfully know, feminism has been stuck, mired, in its own impossible contradictions in ways that have palpably yearned for a release into the "post"-- a post, any post! So long as it can be an "out", so long as we can freely find a place of exit, an a-topical if spectacular 'way out' of feminism's own oppressive self-annihilation.

For Beauvoir, to whom we owe the fist comprehensive study of alterity and sexual difference, as well as for Foucault and for Blanchot, the "outside" is not an empty space. Out of her extensive interrogation of otherness as embodied in the subject-position that women must assume in relation to men, woman emerges as a subject of the outside and as such becomes the quintessential subject of plurality and difference: a subject written only in the plural. "The Other is multiple," Beauvoir writes in a profound departure from her Sartrean -and possibly even Hegelian and Cartesian background to found a "her"itage of an other kind, and "on the basis of this new questions arise" (1991, 144). Through a series of contested turns in the history of modern feminism and a dizzying plurality of editions of her work, this important insight presents the "outside" as the exponential and discursive ground for the theoretical project of feminism as we know it today.

Riding what can only be termed a "Third Wave" of feminist theory, Beauvoir's legacy today (in all its forms) tells us more than something about the category of women; it tells us about the differences, diversities, deviancies, deviations and discrepancies of situations amongst "women;" it tells us something not only about living in the world of others, but that, happily, the world is the others: e.g. it is the outside. However, for Beauvoir, this "outside" does not necessarily

${ }^{14}$ From Blanchot, "Celui qui ne m'accompagnait pas" (Paris, Gallimard, 1953) 125; qtd. in Foucault (1966) 23. 
sum up (the Other as) a foreign or hostile force, but a singularly connective tissue to ourselves ${ }^{15}$.

The body (like the text) is not closed into the instant; it implies a whole history, and even a pre-history (Beauvoir 1945); it implies a connection with the body of others and with other bodies. Let us remember that Beauvoir proceeds to draw on Merleau-Ponty's image of "the fold" to conceptualize a body that is made and unmade in-theworld, at once from the-outside-in and from the inside-out, and presents it as a more adequate model of embodied subjectivity than Sartre's infamous "hole of being" $(1945,367)$. "C'est pourquoi ma conscience se trouve 'engorgée par le sensible'. Elle n'est pas un pur pour soi, ou selon le mot de Hegel que Sartre a repris, un trou dans l'être, mais plutôt 'un creux, un pli qui s'est fait et qui peut se défaire'" (ibid., $367){ }^{16}$

${ }^{15}$ The materiality of the void/outside in Beauvoir's phenomenological ontology is conceived as both as a site of oppression and of liberation. As the very fullness of the void as a space that simultaneously "holds and separates" (Foucault 1966, above), Beauvoir radically challenges the law of non-contradiction. Thus a particular situation, shared by men, bypasses the elemental nature of the outside and becomes raised up as a universal law and a universal function. See Jocelyne Leblanc "L'hystérisation du corps des femmes: Une archéologie de la différenciation sexuelle dans la médecine," doctoral dissertation in sociologie, Université de Québec à Montréal, 1999, a thesis on the root of a specifically masculine economy of desire.

${ }^{16}$ Using this logic one can understand the rationale that would have reproduction be consistent with desire and pleasure. According to Bataille, the erotic is defined by the incommensurability of pleasure and the end(s) of reproduction not only because sexual pleasure is independent of sexual reproduction; but also because of the fundamental meaning of biological reproduction itself. For reproduction presumes the autonomy of independent and discontinuous beings, distinct from one another. See Georges Bataille, L'érotisme (Paris: Minuit, 1957) 17. By contrast to reproduction, death appears as the possibility of union and continuity (ibid.). In this sense, we see the active reversal of the idea that the species-continuity of "man" must be entrusted to woman. Here, man qua "man," one for whom pleasure and reproduction coincides with pleasure (ejaculation), is returned to a state of primal agony by virtue of his desire for species-continuity. The "collapse," the ruin, that is experienced as "the space that separates" 
As we know, Sartre's philosophy was not able to provide a theoretical foundation for his growing commitment to the project of socialist revolution (Kruks 1998, 47). Indeed we are currently seeing a "paradigm shift" in which a Sartrean philosophical foundation is no longer assumed for Beauvoir's The Second Sex, a thesis radically challenged by discoveries based on posthumous texts (Simons 1999a; 1999b). Beauvoir's particular tour-de-force was to twist the Hegelian rhetoric onto itself. Working with "the negative principle of human life" she was able to transform it into a positive force by dint of her appeal to the outside. "Outside" of any biological imperative that would fix female essence before existence, she gave multiplicity, tension, ambiguity, struggle the value of possibility.

\section{Outside (of) Gender}

Today, global celebrations of the 50th anniversary of the publication of Beauvoir's Le deuxième sexe, whose vicissitudes of translation and dissemination defy geographical and national boundaries, bring Beauvoir from the status of the greatest feminist thinker of the post-war period to one of the most profound thinkers of the 20th century; one who changed what it meant to "become a woman" forever. However, while changes in feminist trends have been helped by the availability of her work, they do not reflect or contain it in any way at all. It/she remains "outside" their depth. To be somewhat bold I would say that we have to get outside the "impasse," or "dilemma," of an antagonism between essentialist and differentialist (constructionist) positions $(\text { Kristeva } 1981)^{17}$ to reach a full-blown appreciation of her work.

(Foucault 1966) by man in the face of this radical incommensurability cannot be underestimated. The virtual "alienation" of his sperm from his subjectivity is a situation that has been remarked upon by Mary O'Brien in The Politics of Reproduction (1981), but has remained little explored as an account of man. Bataille speaks of this as a primeval trouble ("trouble élementaire," ibid.). It may be equally useful to think of it as "the male problem," a "trouble" that is specific to the male sex and that engenders female trouble.

${ }^{17}$ Julia Kristeva's article "Woman's Time" (1981) outlines the evolution of the stages of feminism without bringing us to any resolution. Thus from "stage one," the political demands of women's struggles for pay equity, through the "second phase" that seeks to give a langauge to the intra-subjective corporeal experiences of women, feminism moves to a "third space' that does not exclude the other two (ibid., 33). For Kristeva, however, the "existential feminists' together 
Feminism, as we know, as an intellectual and political movement borne out of Beauvoir's philosophy has been given to conceive of gender as its ground of location. However, it has been led to rethink the relation between sex and gender as a relation between "the constructed" and "the given" as if these were two independent, preexistent and autonomous fields. However, "gender", it must be remembered is a fairly recent invention. In the work of Simone de Beauvoir it was not yet present. Arising from a "second" wave of feminism, the term "gender" has already seen its end. As Sonia Kruks reminds us in a recent interview "the latest batch of gender theorists 'went too far' in declaring that it is culture not biology, that determines what are male and female traits." ${ }^{18}$ Yet another "wrinkle in our knowledge" (Foucault 1970, xxxiii), it too may be disappearing, like the face of man in Michel Foucault's famous passage in The Order of Things $(1970,342) .^{19}$

What is to take the place of "gender"? We return to question of biology and sex asking what it means to have left them, even so briefly? Where had we been before? Where are we now? As the new age dawns we are given to ask: What comes after The Second Sex? As well as after the almost 2,000 years of questioning before her? The division between the sciences (between the empirical and the human sciences) breaks down and the boundaries are being rethought through the category of woman, through the place of gender, through the relation between biology and sex or sexuality. In some cases, biology itself is being rethought. What is the impact of this on women? On men? On changes in our society? On the society (yet) to come? In the new "wake" of

with the suffragettes belong to the first stage. Lillian Robinson, current Principal of the Simone de Beauvoir Institute, flips this idea on its head, placing Beauvoir at the horizon of this "third space." Once asked the question "What is the opposite of essentialism?" her answer is not constructionism, but: "Existentialism!"

${ }^{18}$ Sonia Kruks cited in an interview with Patricia Cohen, "Simone de Beauvoir Is Emerging From Sartre's Shadow," The New York Times/Arts \& Ideas (Saturday September 26): B8-B9.

19 "It is no longer possible to think in our day than in the void left by man's disappearance. For this void does not create a deficiency; it does not constitute a lacuna that must be filled. It is nothing more, and nothing less, than the unfolding of a space in which it is once more possible to think" (Foucault 1970, 342; my emphasis). 
feminism, we are freshly reminded of the ever-incipient return of an unsettling "post-feminist" turn. ${ }^{20}$

Contemporary research on the body (phenomenologies of the body, anthropology of the body, psychoanalysis of the body, feminism and the body, sociology of the body and all of cultural studies: with such emergences as "imaginary bodies," "volatile bodies," "sexy bodies," "Black bodies", inter alia.) have brought to new visibility the difficulty of constituting the body: of finding a boundary between the inside and the outside of the body, the constructed and the given, the cultural and the natural, indeed between the biological and the ideological.

I would like to suggest that the "eclipse" of gender anticipates a historical and cultural complex that inaugurates a 'beyond' to the impasses of contemporary feminism and a 'way out' of the blocks of its institutionalization as Women's Studies. My argument here is that Beauvoir's work is not only to be celebrated as a historic landmark for feminism. Even more importantly, it opens up a new frontier for/of feminist theory today. For these are indeed crisis times, ones that call for a new mutation in the terms of feminist engagement.

To get at the crux of this challenge, so bound up in and with the elusiveness of "work" is, by my thinking, to see her opus in its absolute singularity, as well as in its utter dissolution into "the outside": into the lived exteriority of our everyday relations of power, force, resistance, and struggle; our connection with "theory", "post"-theory, and institutional development of the Academy; and with all the forces of desire, power, and sociality that are given to us to transform and that transform us as we speak.

As a work of the outside, the work of Simone de Beauvoir draws itself out of the past, from a "pre-Beauvoirian" feminism (a feminism which Beauvoir nevertheless managed to inflect into its own regional, geographic, historic, and political form), into an "open future" as this new and indeed 'contested' legacy of Beauvoirian "thought" ${ }^{21}$

${ }^{20}$ See the article "Is Feminism dead?", TIME, Canadian Edition, vol. 151, no. 25, (June 29, 1998).

${ }^{21}$ For discussions of the debates surrounding Beauvoir's heritage, see Catherine Rodgers Le deuxième sexe de Simone de Beauvoir: Un héritage contesté et admiré (Paris: Harmattan, 1998) and Sylvie 
offers up an ingenious 'way out,' a spectacular and a-topical place of 'exit,' a 'flight' and an 'escape' from the mire of contradiction and impasse that has beset the Second Wave; its endless polarizations between essentialist and differentialist/constructionist positions.

A "philosophy of the limit" (Cornell 1992), par excellence, Beauvoir's thought from outside has many aspects. However, its most significant one for feminism is that it can significantly move us beyond the stalemate of essentialism precisely by anticipating it and its "beyond." The stark face-off between biological reductionism and social constructivism find a shared space in the corpus of her thought. An altogether new body enters the scene of feminism (the toxic body, the othered body, altered body, marked, mutilated and remade, refurbished, refabricated, redesigned with each new moment of our singular and collective existences), bringing us the relation between biology, sex and gender, as though for the very first time, into language, desire, corporeality and the body-subject's own embodied singularity.

By emplacing an existential framework, in lieu of only a psychoanalytic, materialist, or biological account, Beauvoir steals the master's tools to give feminism its arsenal: if existence precedes essence, none of these accounts can fully ensure or guarantee the destinies of women. The possibility of gender as choice, a freely assumed project of negotiation, submission, or resistance, is, in the work of Judith Butler, one extension of this ground of existence. ${ }^{22}$ Butler addresses "the internal ambiguity of gender as both 'project' and 'construct"' $(1986,37)$ and implements Beauvoirian position that accommodates an "outside of gender" (ibid., 37) in which is borne the feminist concept of the embodied body: "the body is not a static phenomenon, but a mode of intentionality, a directional force and mode of desire" (ibid., 38).

Chaperon "La deuxième Simone de Beauvoir," Les Temps Modernes 52, 593 (avril-mai 1997): 112-143. See also my article "Beauvoir: Un héritage du dehors," (Alexander 2000b).

${ }^{22}$ Judith Butler develops her position on gender in her complex reading of Beauvoir in Gender Trouble (New York: Routledge, 1990) as well as in the two essays: "Sex and Gender in Simone de Beauvoir's Second Sex," Yale French Studies 72 (Winter 1986): 35-49; and in "Gendering the Body: Beauvoir's Philosophical Contribution," Women, Knowledge and Reality: Explorations in Feminist Philosophy, eds. Ann Garry and Marilyn Pearsall (New York: Routledge, 1992). 
To think of a body "beyond itself" touches on the "ek-static reality of human beings [which] is, however, a corporeal experience; the body is not a lifeless fact of existence, but a mode of becoming" (Butler, ibid. 38). ${ }^{23}$ Another extension of this thought is to be found in Spivak, who addresses the existential concept of the Other as the Mother. "The Mother" chapter of The Second Sex in which "Beauvoir rewrote the figure of the Mother as possible existential subject." According to Spivak, who follows "the protocols of Beauvoir's text into existentialism" through her study of the Mother, Beauvoir's is a "reduced or pared-down structural picture of the Other, she writes:

Her [Beauvoir's] reduced or pared-down structural picture of the Mother, so intimate that it is intuitively inaccessible (and thus protected against dominant universalizing), is theoretically inclusive of "situations" (an existentialist word) often considered beside the point of the norm: gay parenting, mothering by the gendered subaltern. ${ }^{24}$

In this regard, Beauvoir's new legacy, her feminism of the outside, offers up not only a non-discriminatory philosophical frame for feminism, but an altered strategy, one more duplicitous and infinitely more hypo-critical than hitherto assumed, for escaping these polarizations in feminism and in the social sciences and humanities generally: especially, I might add, one more suited to work in the interests of women in the context of how we approach the question of gender, and, at the next horizon, the question of the Mother. ${ }^{25}$

\section{A 'Way Out' for Feminism}

"Now, what peculiarly signalizes the situation of woman," writes Beauvoir in her famous "Introduction" to The Second Sex, "is that she--a free and autonomous being like all human creatures-nevertheless finds herself in a world where men compel her to assume

${ }^{23}$ For a contemporary French take on Beauvoir's ex-static subject see Rétif (1998). A discussion of Rétif is found in my essay "Beauvoir: Un héritage du dehors" (Alexander 2000b).

${ }^{24}$ Gayatri Chakravorty Spivak "French Feminism Revisited: Ethics and Politics," in Feminists Theorize the Political, eds. Judith Butler and Joan W. Scott (New York: Routledge, 1992), 58-59.

${ }^{25}$ See my forthcoming book Mother Trouble: Beauvoir and Feminist Ethics. 
the position of the Other" (Beauvoir 1989, xxxv). Describing the world in which women must live, Beauvoir's Second Sex envisages "the difficulties in their way as, endeavoring to make their escape from the place hitherto assigned them, they aspire to full membership in the human race" (ibid.), from both the inside of a corporeal body-subject "that is called 'the sex"" (ibid., xxii), and from the outside: "how the concept of the 'truly feminine' has been fashioned--why woman has been defined as the Other--and what have been the consequences from man's point of view" (ibid., xxxv; my emphasis).

Woman, qua 'sex, ' as a corporeal, double-body subject is established as of her "Introduction": "thus she is called 'the sex,' by which is meant that she appears essentially to the male as a sexual being (un être sexué). For him she is sex--absolute sex, no less" (xxii). This double body-subject that Beauvoir's Second Sex engenders through the notion of woman as "Other" to man presents the body of woman in all its duality: ${ }^{26}$ as both 'an instrument' and 'a situation,' both a 'thing' in the world and a 'point of view,' both the presence of an 'inside' of the body and 'an outside.' This double body-subject, borne out of Beauvoir's treatise on woman, is also explored in her treatise on old age (1977), a work that structurally coheres even more explicitly around the epistemological division between knowledge of the body from the outside and knowledge from inside. ${ }^{27}$ In the body of The Second Sex the

${ }^{26}$ For a discussion of Butler's and Le Doeuff's contribution to a feminist appreciation of Beauvoir's two concepts of body see Alexander (1997). Julie K. Ward develops the idea of Beauvoir's dual concept of body in her essay "Beauvoir's Two Senses of 'Body' in The Second Sex." In Feminist Interpretations of Simone de Beauvoir, ed. Margaret A. Simons (University Park: Penn State University Press, 1995). See also Catriona Mackenzie "Simone de Beauvoir: Philosophy and/or the female body." In Feminist Challenges: Social and Political Theory, eds. Carol Pateman and Elizabeth Grosz (Sydney: Allen and Unwin, 1986). In France today, the new. appreciations of Beauvoir's "contested" heritage point to the presence of contradiction and ambiguity in Beauvoir's work, clearly manifested in her concept of dual concept of body, as a sign of its longevity and hidden strength (Rodgers 1998; Chaperon 1997).

${ }^{27}$ In the "Preface" to Old Age she writes: "Every human situation can be viewed from without--seen from the point of view of an outsider -or from within, in so far as the subject assumes and at the same time transcends it. For the outsider, the aged man is the object of a certain 
division is expressed by the two tomes: I, "Facts and Myths," and II "Woman's Life Today." In the French text the division is singularly clearer, drawing upon the key phenomenological principles of Maurice Merleau-Ponty and his summarily fecund notion of "expérience vécue. ${ }^{28}$ Thus Tome I, "Les faits et les mythes," covers the ground from the outside of woman's body, and Tome II, "L'expérience vécue" from the inside of that body. What is to be remembered, however, is that these are not two separate, bounded, independent realms. Nor are they cut of the cloth of an outside that is projected by a masculine interiority. "To put oneself 'outside' is still a way of living the inescapable fact that one is inside" $(1991,76)$. The necessity of a nonconstructivist, non-reductionist position calls up the possibilities explored by her contemporaries, but with a difference. For, she writes: "those French intellectuals who, in the name of history, poetry, or art, sought to rise above the drama of the age, were willy-nilly its actors" (ibid.).

Beauvoir prefers to "steal" the Master's tool and work it to her own ends: "the problem is to steal the tool," she writes in her 1974 introduction to "Les femmes s'entêtent" (Beauvoir 1981, 191), not fully knowing the extent of the subterfuge afforded her by what is outside the 'outside,' and hence outside the very 'outside' $/$ inside' division itself.

knowledge: the aged man himself experiences his condition first hand-he has an immediate, living comprehension of it. In the first part of this book I shall adopt the first viewpoint: I shall examine what biology, anthropology, history and contemporary sociology have to tell us about old age. In the second I shall do my best to describe the way in which the aged man inwardly apprehends his relationship with his body, with time and with the outside world" (Beauvoir 1977, 16). She also writes at the outset of Part II: "Hitherto we have looked at the aged man as an object, an object from the scientific, historic and social point of view: we have described him from the outside. But he is also a subject, one who has an intimate, inward knowledge of his state and who reacts to it" (ibid., 313).

${ }^{28}$ According to Margaret Simons' breakthrough study, this translation "effectively masks the significance of the work as a phenomenological description (a factor which might contribute, but not fully account for the nearly universal failure of contemporary American phenomenologists to acknowledge the contribution of Beauvoir in The Second Sex to the articulation of a phenomenological analysis of the social world" (Simons 1983, 563). 
Without positing the absolute hold of the outside upon any interiority, Beauvoir produces the template for an altered treatment of the subject of woman: woman as subject as well as object of the outside. Kate and Edward Fullbrook point out that Beauvoir's is an "ethical analysis of major human abuses which depended on fallacious deployments of subject and object, of embodiment, and of intersubjectivity" (1998, 116). In my own work I explore its value as an altered treatment of women's self abuses with particular emphasis on women's addiction, and especially women's smoking addiction (see Alexander and Roberts 2001).

The Beauvoirian transformation of the phenomenological description of the world in light of our experience of other persons, also echoed by studies of the role of the subject found in Levinas (1994), profoundly challenges the model whereby the inside (as subjectivity), is a locus which defines the outside. Instead, the outside emerges as the dissolution of the interior and exterior division altogether. The 'duplicity' afforded by this new model has strategic applications for feminist work. A model of strategic ambiguity emerges that occupies the space of the ellipsis: the space between the use of "'man' to denote all human beings irrespective of gender and the use of 'man' to refer to specifically 'male' human beings" (Kruks 1989, 69). ${ }^{29}$ As for example, when she writes: "In actuality the relation of the sexes is not quite like that of two electric poles, for man represents both the positive and the neutral, as is indicated by the common use of man to designate human beings in general; whereas woman represents only the negative, defined by limiting criteria, without reciprocity" $(1989, \mathrm{xxi})$.

This is the type of experience in which, according to Levinas' philosophy of alterity, something is given to me; indeed thrusts itself upon me, that can never be translated as a meaning" (Levinas 1993). Beauvoir's critical understanding of Levinas' claim that the experience of the other, which is precisely an experience of something that manifests itself as not mine, is more than the thematic content of my own consciousness, because it is based on the experience of becoming woman, radically differs from his. By way of her refusal to accept

${ }^{29}$ Kruks is, in this passage, in fact misreading Beauvoir, failing to grasp the strategic ambiguity of Beauvoir's own ambiguous use of 'man.' 
Levinas' reduction of this experience to a phenomenological position, ${ }^{30}$ a position that fails to take into account woman's subjective relation to her position as the Other, Beauvoir configures the outside not only as thought itself, but also as force and as movement.

Beauvoir managed to ingeniously slip past this limitation, bringing into effect a resistant reading of this "negativity," through an existential reading of the void. Now no longer an empty space, this void takes its place as the "outside," a space that simultaneously "holds and separates" (Foucault, 1987). In a strangely Beauvoirian turn, Sartre points out in his famous essay "Intentionality": "consciousness has no "inside'; it's nothing but its own outside, and this absolute flight, this refusal of substance, that makes it a consciousness" (Sartre 1992, 389). Not only are we henceforth able to understand the subject of woman as both as subject and an object of feminist inquiry, we are also given a means for exiting some of our more divisive impasses: paralyzing questions about our "we"-ness (Finn and Godway 1994). "Strategic essentialism," whatever its merits as strategy, is still centered on essentialism. ${ }^{31}$ What exactly binds the subject of feminism, stabilizes women as subjects? Indeed, "what constitutes, or ought to constitute the category of women?" (Butler 1990, 1)?

Relying, instead, on a strategy of ambiguity throughout The Second Sex -- a 'strategic ambiguity' that implies the strategic uses of ambiguity -- Beauvoir works feminism's 'operative viewpoint' (Le Doeuff 1989) to the max. Via a consistent and deliberate use of two concepts of body, which borrow heavily from her earlier 1947 Pour une morale de l'ambiguïté, Beauvoir returns to all of us our 'heritage': as a heritage of the outside. "'Rational animal,' 'thinking need,' [man] escapes from his natural condition, without freeing himself from it"

${ }^{30}$ See the famous second footnote to the "Introduction" of The Second Sex (Beauvoir 1989, xxii); the first being to the then newly released Kinsey Report.

31 "The debate between essentialism and anti-essentialism is really not the crucial debate. It is not possible to be non-essentialist, as I said: the subject is always centered. The real debate is between two ways of representing." Against the exhortation "I will not be an essentialist," Spivak, whose argument for "strategic essentialism" suggests that "what it [the debate] has to take into account is that the 'essence' that is being represented is a representation of the other kind" (Spivak 1990, 109; my emphasis). 
$(1991,7) .{ }^{32}$ Following Beauvoir, "a new paradox is thereby introduced into his [man's] destiny" (ibid.). On the opening page of The Ethics of Ambiguity she explains its systemic hold:

As long as there have been men and they have lived, they have all felt this tragic ambiguity of their condition, but as long as there have been philosophers and they have thought, most of them have tried to mask it. They have striven to reduce mind to matter, or to reabsorb matter into mind, or to merge them within a single substance. Those who have accepted the dualism have established a hierarchy between body and soul which permits of considering as negligible the part of the self which cannot be saved. (ibid., 7-8)

As a heritage of the outside, Beauvoir's The Second Sex belongs to no one and to all. Not only does this heritage bring the "nature" of the body out of its status as a crass materiality into an assumed philosophical project; her legacy takes the "nature" of woman into the fold of a "philosophie engagée": an assumed project of identity in compliance, negotiation, or resistance; an active project of corporeal engagement not unlike Foucault's process of "subjectivation" or Deleuze's complex notion of "becoming" (Schrift, 1995), both of whose debt to Beauvoir is salient.

Beauvoir's existential ethic is not along the lines of a Sartrean "ethic of authenticity," as Michèle Le Doeuff suggests (1989), but rather, along the lines of her own well-developed ethics of "ambiguity" (Beauvoir 1991). The value of such a reading in understanding some of the seemingly contradictory strains in her account of woman's experience -- the unpopular lesbian chapter in The Second Sex is a case in point -- cannot be overestimated. [I am currently exploring the value of Beauvoir's ethic for feminist queer theory].

The possibility of a plurality of fields and a fluid set of parameters in measuring degrees of consent within conditions of

${ }^{32}$ Cf. Québec Finance Minister Bernard Landry, who will be running for PQ leader, was recently perceived in poles as "too rational." Consider how, in this context, rationality in a politician assumes the status of a liability. 
frustration and oppression ${ }^{33}$ profoundly challenges the idea that woman's destiny is inevitably determined by physiological, psychological, or economic forces. Without denying their force in creating the foundations for biology, psychoanalysis, and historical materialism, Beauvoir nevertheless presents us the subject of woman in all her otherness, and "in that freedom by which he [she] escapes" $(1991,67)$. Therein lies its strength for a feminism of the outside, outside genders and without borders; also a feminism (thankfully) without eternity.

Beauvoir's landmark treatment of the exorbitant status of womanhood lays bare the structures that bind and then destroy the Other through sex. ${ }^{34}$ Hence, the non-reductionist "malheur spécifiquement féminin" that Beauvoir's The Second Sex elucidates. ${ }^{35}$ French feminism has pursued this strain much more modestly by deepening our understanding of "the status of womanhood" in specifically Western theoretical discourse, borrowing heavily from Beauvoir's analysis of woman's aleatory specificity (Marks and de Courtivron, 1981)]. The rendering visible of the asymmetrical positioning of woman in relation to man, a 'status' contained in the idea of 'gender' and indebted to Beauvoir's reading of Lévi-Strauss (see Butler 1990), is based on her performance of a startling sleight of hand. Her ingenious double exposure of: a) the insistent and phallacious deployment of the subject-other relation, as well as, b) its 'gauranteed' hegemony by virtue of a strategic appeal to "nature," an appeal that has nevertheless shifted through time in response to different cultures and

${ }^{33}$ Speaking about "the degradation of existence into the 'en-soi'--the brutish life of subjection to given conditions--and of liberty into constraint and contingence", Beauvoir writes: "this downfall [sic.] represents a moral fault if the subject consents to it; if it is inflicted upon him, it spells frustration and oppression" $(1989, \mathrm{xxxv})$. This is a highly misunderstood passage in Beauvoir, leading critics to think it follows an ethic of authenticity (see for example, Le Doeuff, 1989).

${ }^{34}$ Consider the chilling passage that launches the section on "Myths": "he takes possession of her only through consuming her--that is through destroying her" $(1989,139)$. Further she continues this line thus: "there is a hoax in marriage, since, while being supposed to socialize eroticism, it succeeds only in killing it" (ibid., 187).

${ }^{35}$ See Beauvoir's interview with Welfrid Le Moyne for CBC Radio Canada (1959). For a discussion of this interview, see Francine Descarries La parole Metèque 31 (March 1999). 
conditions of existence. In this respect, Beauvoir's philosophy of embodiment and intersubjectivity, as well as her altered ethics of alterity itself, were "exceptionally well-placed" to show that "philosophy and experience were of a piece" (Fullbrook 1998, 116). ${ }^{36}$

Thus the subtle brilliance Beauvoir's thought, shimmering in its live filaments across the pages of her work, is a thought still to be discovered: a thought from the outside and an outside (of) thought. This is a 'thought' that responds not only to possibilities of action, but also to the possibility of the mutations in the very pressing "matter" of the other: ${ }^{37}$ the very "stuff" that "subjects" are made out of (e.g. the bodysubject, the body, Woman, etc.); from whence emerges her own very engaging concepts of corporeality, 'situation', and 'lived' experience; her ethics of 'alterity', now recognized as an ethics of 'joy' and

${ }^{36}$ When at Concordia's polyvalent Simone de Beauvoir Institute Institute we celebrate the diversity of Beauvoir's heritage "in-situation," we are reminded that it is not only the rigor and abstraction of her thought that made Le deuxième sexe/The Second Sex so influential, but also the attention that she gave to the vulnerability of systemic principles to the example, the instance, the particular situation: the singular, the queer, the monstrous, the banal. This attention to the materiality of culture and to cultural locality is precisely that which throws open Beauvoir's universality-in-particularity that makes it so extraordinary a frame for doing feminist work.

This means that for us at the Institute, celebrating Simone de Beauvoir is celebrating 20 years of Women's Studies through a shared place in time. In these years, Annexe MU at 2170 Bishop has given us a "place" built upon the tracks of a plurality of others: subaltern communities (the traders of sex and sexuality that memorialize our premises), the hybridity of the women's movement in Québec, the heterogeneity of our shared identities and experiences (Alexander 2000a).

${ }^{37}$ Thus my argument throughout is that the "outside" (le dehors) is a more adequate figure for thinking about "situation" as the materiality of culture, social relations and the social. It is located outside binary terms, written in the name of the pluralities of the singular, restores the imbrications of autonomy and connection (contact, intimacy, care), ensures the inversion of the inside/outside dimension of the body as a space that at once separates and holds (Foucault, above), and inheres in the abjection of spaces outside socially accepted norms of sociality (I develop this elsewhere in relation to Beauvoir's queer ethics). 
'generosity' (Bergoffen 1997), is also a feminist ethics of the outside. This is an ethic that not only makes the meaning women "matter" (Alexander 2000a), but also assumes the superiority of "risking life" over that of "giving life". ${ }^{38}$

The experience of the Other -- of the other human being -- is precisely such an experience of the outside -- an experience that thrusts itself upon the subject in subversion, inversion, perversion conversion. The subject, permanently marked as a subject of the outside must, in Beauvoir's terms, assume "the risks of finitude, vulnerability and the bond" (Bergoffen 1997, 6).

\section{A Heritage of the Outside}

An invaluable tool for articulating the diversity of our "situations whose particularity is precisely a universal fact" (1991, 144), Beauvoir's thought and heritage of the outside makes of these "new questions" an ethical, as well as a methodological end of women's studies: indeed, this thought opens into the study of women precisely by "taking the other as an end" (ibid.). Not just a ground for reform, but also one for transformation and change, Beauvoir's legacy of the outside, of location and of exteriority, is especially instructive; a crucial link between ontology and the ethical and political domain it grounds an ethic of the outside which will "refuse to deny a priori that separate existents can at the same time be bound to each other" (Beauvoir 1991, 180).

38 "For it is not in giving life but in risking life that man is raised above the animal" (Beauvoir, 1989, 64). "To put it positively, the precept will be to treat the other...as a freedom...in using this conducting-wire one will have to incur the risk, in each case, of inventing an original solution" (Beauvoir 1991, 142). Beauvoir's radical existential ethics of the other is an ethics of risk in that it depends upon a rejection of every principle of authority, the rejection of any a priori and secure base for action. Comfortable with contradiction and ambiguity Beauvoir's feminist tactics in the production of feminist theory are guided by a self-avowed desire to perturb: "our only desire is to disturb." In her Introduction to "Les femmes s'entêtent" she writes "the anti-sexist struggle attacks in each one of us what is most intimate and what seemed the most secure" (Beauvoir 1981, 192). "The readers-men or women--who come to these texts in good faith run the risk, when they have finished reading, of feeling that they have been challenged" (ibid.). 
The social dimension of Beauvoir's thought from outside. An outside presents an "outside" where: "violence and oppression are not only dyadic relations of self and other. They are embedded in a world of multiple projects and their complex interferences'" (ibid., 71). A logic that Sartre had not attempted to examine in his own work, Beauvoir's conception of a "common situation" that can give rise to a "common project" constitutes her own non-Sartrean account of social existence. Her "thought from outside" implies that a collective freedom is indeed possible and that "multiple relations can cohere into intelligible forms with a degree of temporal permanency"(Kruks 1998, 53).

Sonia Kruks examines, in her essay "Beauvoir: The Weight of Situation," Beauvoir's notion of "coherent ensembles"(Kruks 1998, 54). However, this "non-Sartrean account of social existence" (ibid.) can only make "sense" to us as a project of desire. The "ecstatic thrust" (Lingis 1980, 220) of Beauvoir's investment, her self-propulsion into the outside takes on what Alphonso Lingis calls, "the pulse of care" (ibid., 226). Her connection with "the many" reflects the fact that "responsibility is coextensive with our sensibility' (ibid., 226). At the close of her section in Tome II of The Second Sex on female mysticism/masochism, the last rung of female failure prior to liberation, Beauvoir writes the following on the topic of feminine freedom: "There is only one way to employ her liberty authentically, and that is to project it through positive action into human society" (Beauvoir 1989, 678). That is: into the outside. The call for a collective and communal project of the outside is unambiguous.

Those who thought that she was upholding a radical, individualist, idealist morality and "ethics of authenticity," or conversely, those who thought she was supporting constructivist determinisms, will be surprised. Her position on the "interdependence of freedoms" (Kruks 1998, 47), being what distinguishes her from Sartre and what pulls her in line with a wave of postructuralist positions, has yielded the possibility of an 'out' of a different kind. Besides transcending the impasse of feminism, Beauvoir's philosophy of the outside, and of the possibility of collective action, yields a philosophy of negativity that is not based upon desire as lack but as movement: e.g. as the positive force of social life itself. As Kruks eloquently paraphrases Beauvoir:

Although I freely create my own project, its meaning for me 
depends on the existence of other people and their willingness and ability to confirm its significance. Above all, they must be willing and able to take up my creation and give it a future that goes beyond my present.... what I am able to obtain through others is a future: my project remains open beyond the end of my act, even beyond my death, if others take it up and use what I have created as the starting-point for their projects." (Kruks 1998, 48)

By contrast, it is precisely the lack of "an open future" (Beauvoir 1991, 91) that condemns women more than the "lack" of anything else.

In this "sense," the notion of "situation" is incomplete as explanatory force. Beauvoir's absorption into the outside, the submission of her text to what is Other to itself, as in the Four Square edition of The Second Sex, is not just the stubborn site of a remarkable collapse: a "ruin" that escapes the dynasty of representation. It is the site of an event: an ontological upsurge that also "escapes" the dynasty of representation. Do we not reproach her inevitably from one or another position of extreme exteriority even as we praise her? At the same time, in its failure to remain what it is -- stable, fixed, coherent with all aspects of itself -- her text expresses a "sense of vulnerability, not made of anxiety over the immanence of nothingness" but of what $\mathrm{Al}$ Lingis calls "the liability of being wounded and rent and pained by the force and substantiality of the sensuous element" (Lingis 1980, 223). This "element" of the outside is not an object, or even just the place where multiplicities adhere and accumulate: it is a threshold space, a site of contact between bodies, the brush of contiguity and contact that exists between bodies and between texts. "The appeal and demand of the other [that] surfaces on the skin," writes Lingis, "is not a hide, camouflage, or container, but a surface of exposure that hollows out wants and lacks" (Lingis 1996, 101); it is the possibility "to surpass the given toward an open future" (Beauvoir 1991, 91).

Like words of consecration between lovers, this appeal of the outside functions "to intensify a surge of vitality generating excess energies. Their expression sends forth those energies in expenditure without return" (Lingis 1996, 107). Beauvoir's notion of generosity and equality cannot be separated from her ethics of eros as an ethics of the outside, an ethics outside of ethics as traditionally conceived. In this she has much in common with others of her generation struggling to free philosophy from (the shackles of) the hidden and absolute, "walled-in" 
interiority of the autonomous, self-identical, and coherent, masculine subject. If women are the subjects of the outside par excellence, then Beauvoir has succeeded in making their meaning matter. Upon that the failure and the success of her elusive text simultaneously rest.

\section{Outside the Other Second Sex}

As a final testimony of the extraordinary exteriority of (the body of) Beauvoir's text, I will quote a passage from outside the second, indeed the "other" Second Sex. This is a passage that appears in the opening page of the Four Square Edition (1960), reprinted in March, 1964, and which presents the book to the reader as a work of "the first importance," "the best book on women ever written." It goes like this:

Can man ever understand woman?

In what is probably the most brilliant and revealing study of woman ever written, The Second Sex lays bare all the feminine mysteries. Here is woman in all her aspects -- the young girl, the married woman, the lesbian, the prostitute, the woman in love, the independent woman. Above all, in her relation to man. For man can think of himself without woman, but woman cannot think of herself without man.... The celebrated French novelist, Simone de Beauvoir, writes of her own sex with wit and feminine perception, but also with the most cruel logic. There is no evasion in discussing even the most intimate biological reactions: she is as down-to-earth as only a Frenchwoman can be. (Beauvoir, 1960)

One might argue that in light of the above we cannot truly celebrate Beauvoir's failure to control the outcome of her work; yet we can celebrate the originality of her thought as residing in the live tension between certain radical speculative movements and the wish to practice, and even to institutionalize, the speculative process itself (such as, for instance, the between feminism and the institutionalization of Women's Studies). A "failure" also attributed to other thinkers about whom there have been wars, ${ }^{39}$ this kind of tension (ambiguity) serves to push to their limits questions about the kind of "thought" particular to women (and feminism). For example, is the feminist reflection on desire compatible with the institutionalization of Women's Studies?

In this sense, as the Four Square Edition of The Second Sex so

${ }^{39}$ Cf. Bersani on Freud $(1986,3)$. 
well demonstrates, the different and often divergent "uses" to which Beauvoir's thought from outside can be put are also the consequences "of the work of thought itself" (Bersani 1986, 6).

If it is difficult to find a language faithful to this thought, it is where reaching toward that outer bound, arriving at its own edge, language becomes directed not toward an inner certainty, unshakable truth, but toward its own continuous unravelling. And here is where Beauvoir's thought from outside, where her heritage, and the legacy its has left us all find their place: in that space, that heterogeneous space that magically separates and holds together at the same time.

Simone de Beauvoir Institute

Anna Alexander

\section{Works Cited}

Alexander, Anna and Mark S. Roberts, eds. 2001. High Culture: Reflections on Addiction and Modernity. Albany: SUNY Press (forthcoming).

Alexander, Anna, ed. 2000a. Heritage In-Situ: The Simone de Beauvoir Institute Review, Vols. 18/19 (Winter).

Alexander, Anna. 2000b. "Beauvoir: Un héritage du dehors," Heritage In-Situ: The Simone de Beauvoir Institute Review, Vols. 18/19 (Winter): 99-110.

Alexander, Anna. 1997. "The Eclipse of Gender: Simone de Beauvoir and the Différance of Translation," Other Openings: Selected Studies in Phenomenology and Existential Philosophy, Volume 22, eds. Debra Bergoffen and John D. Caputo. Philosophy Today 41, 1/4 (Spring): 112-122.

Bataille, Georges. 1957. L'Erotisme. Paris: Minuit.

Beauvoir, Simone de. 1991. The Ethics of Ambiguity. New York: Carol Publishing; 1948, 1976.

Beauvoir, Simone de. 1989. The Second Sex. New York: Knopf, 1952; London: Four Square Edition, 1960; originally published as Le deuxième Sexe. Paris: Gallimard, 1949.

Beauvoir, Simone de. 1981. Introduction to "Les femmes s'entêtent," Les Temps Modernes (April-May 1974). In New French Feminisms: An Anthology, eds. Elaine Marks and Isabelle de Courtivron. New York: Schocken.

Beauvoir, Simone de. 1972. Old Age. New York: Penguin. La vieillesse. Paris:Gallimard, 1970.

Beauvoir, Simone de. 1959, "Beauvoir: Interview with Welfrid Le Moyne," CBC Radio Canada. 
Beauvoir, Simone de. 1947. Pyrrhus et Cinéas/Pour une morale de l'ambiguïté. Paris: Gallimard.

Beauvoir, Simone de. 1945. "La phénoménologie de la perception de Maurice Merleau-Ponty," Les Temps Modernes 1, 2 (novembre): 363-67.

Bergoffen, Debra B. 1997. The Philosophy of Simone de Beauvoir: Gendered Phenomenologies, Erotic Generosities. Albany: SUNY Press.

Bersani, Leo. 1986. The Freudian Body: Psychoanalysis and Art. New York: Columbia University Press.

Butler, Judith. 1993. Bodies That Matter: On the Discursive Limits of "Sex." New York: Routledge.

Butler, Judith. 1990. Gender Trouble: Feminism and the Subversion of Identity. New York: Routledge.

Butler, Judith. 1987. Subjects of Desire: Hegelian Reflections in Twentieth Century France. New York: Routledge, 1999.

Butler, Judith. 1986. "Sex and Gender in Simone de Beauvoir's Second Sex," Yale French Studies (Winter): 35-49.

Chaperon, Sylvie. 1997. "La deuxième Simone de Beauvoir," Les Temps Modernes 52, 593 (avril-mai): 112-143.

Cornell, Drucilla. 1992. The Philosophy of the Limit. New York: Routledge.

Deleuze, Gilles. 1986. Foucault. Paris: Les Éditions de minuit.

Finn, Geraldine and Eleanor Godway. 1994. Who Is This We? Absence of Community. Montréal: Black Rose.

Foucault, Michel. 1970. The Order of Things: An Archeology of the Human Sciences. New York: Random.

Foucault, Michel. 1987. "La pensée du dehors." Critique 229 (juin 1966): 523-446; "Maurice Blanchot: The Thought from Outside," in Foucault/Blanchot, translation by Brian Massumi. New York: Zone Books.

Fullbrook, Kate and Edward. 1998. Simone de Beauvoir: A Critical Introduction. Cambridge, UK: Polity Press.

Grosz, Elizabeth. 1996. "Architecture from the Outside," Space, Time, and Perversion. New York: Routledge.

Kristeva, Julia. 1981. "Women's Time." Translated by Alice A. Jardine and Harry Blake, Signs 7, 1: 13-35.

Kruks, Sonia. 1990. Situation and Human Existence: Freedom, Subjectivity, and Society. Boston: Unwin and Hyman.

Kruks, Sonia. 1998. "Beauvoir: The Weight of Situation." In Simone de Beauvoir: A Critical Reader, ed. Elizabeth Fallaize. London: Routledge. 
Le Doeuff, Michèle . 1989. "Operative Philosophy: Simone de

Beauvoir and Existentialism." Ideology and Consciousness 6: 47-57.

Levinas, Emmanuel. 1994. Outside the Subject. Translated by Michael

B. Smith. Stanford: Stanford University Press.

Lingis, Alphonso. 1996. Sensation: Intelligibility in Sensibility. New Jersey: Humanities Press.

Lingis, Alphonso. 1980. "The Sensuality and the Sensitivity." In Face to Face With Levinas, ed. Richard A. Cohen. Albany: SUNY Press.

Lingis, Alphonso. 1998. The Imperative. Bloomington: Indiana University Press.

Marks, Elaine and Isabelle de Courtivron, eds. 1981. New French Feminisms: An Anthology. New York: Schocken.

O'Brien, Mary. 1981. The Politics of Reproduction. New York: Routledge.

Probyn, Elspeth. 1996. Outside Belongings. New York: Routledge.

Rétif, Françoise. 1998. Simone de Beauvoir: L'Autre en miroir. Paris: L'Harmattan.

Rich, Adrienne. 1986. "Notes Toward a Politics of Location." In Blood, Bread, and Poetry: Selected Prose 1979-1985. New York: W.W. Norton.

Rodgers, Catherine. 1998. "Le deuxième sexe" de Simone de Beauvoir: Un héritage admiré et contesté. Paris: L'Harmattan.

Sartre, Jean-Paul. 1992. "Intentionality (1939)." In Zone 6:

Incorporations, eds. Jonathan Crary and Stanford Kwinter.

Cambridge, Mass: MIT Press.

Schrift, Alan D. 1995. Nietzsche's French Legacy: A Genealogy of Postructuralism. New York: Routledge.

Simons, Margaret A., ed. 1999a. Hypatia: Taking Simone de Beauvoir Seriously as a Philosopher (Fall).

Simons, Margaret A. 1999b. Beauvoir and 'The Second Sex':

Feminism, Race and the Origins of Existentialism. New York: Rowman and Littlefield.

Simons, Margaret A. 1997. "Bergoffen's The Philosophy of Simone de Beauvoir and Beauvoir's 1927 Diary." Unpublished paper presented at The Society for Phenomenology and Existential Philosophy, University of Lexington, Lexington, KY, October 16.

Simone, Margaret A. 1983. "The Silencing of Simone de Beauvoir: Guess What's Missing From The Second Sex," Women's Studies International Forum 6, 5: 559-564. 
Spivak, Gayatri Chakravorty. 1990. The Post-Colonial Critic:

Interviews, Strategies, Dialogues, ed. Sarah, Harasym. New York: Routledge.

Woolf, Virginia. 1977. Three Guineas. London: Hogarth. 